\title{
TUSSEN DIE AARDSE JERIGO EN DIE HEMELSE JERUSALEM. RUTGER SCHUTTE (1708-1784) EN DIE PELGRIMSMOTIEF IN SUSANNA SMIT (1799-1863) SE GODSDIENSTIGE DAGBOEKE ${ }^{1}$
}

\section{Andries Raath}

Navorsingsgenoot, Departement Geskiedenis

Universiteit van die Vrystaat

RaathA@ufs.ac.za

\section{ABSTRACT}

Rutger Schutte (1708-1784), the pietistic author of popular hymnbooks, composed his spiritual verses at a time the religious culture of Pietism was approaching its zenith in the Netherlands and other European countries. In addition to his contribution to Een Nieuw Bundeltje Uitgeknipte Geestelyke Gezangen [A new collection of suitable spiritual songs] (third edition, 1721), he composed three collections of Stichtelijke Gezangen [Edifying hymns] from the early 1760s. In addition to the extensive prefaces in these collections, Schutte added long annotations, thereby creating the impression of academic depth - a style which elicited much criticism. However, Schutte's hymns introduced a new popular culture of hymn-singing. At the time of his death his hymns had found staunch adherents in many spheres of life. This essay identifies several themes central to Schutte's hymns: the quest for practical piety; the tension between the heavenly Jerusalem and the earthly Jericho; and the spiritual marriage bond between Jesus and the believer. These themes also surface prominently in the spiritual diaries of the Voortrekker woman Susanna Smit. The entries in her diaries from the early 1840s reflect extracts from Schutte's hymn "The voyage to Jerusalem" in particular. Her descriptions of and reflection on the metaphor of the Christian pilgrim's voyage to the eternal Jerusalem served as an important point of reference in her spiritual exercises.

Key words: Pietistic; spiritual hymns; heavenly Jerusalem; earthly Jericho; Christian pilgrim

1 'n Woord van opregte dank aan Frans Huisman (Vrije Universiteit, Amsterdam) vir die beskikbaarstelling van waardevolle navorsingsmateriaal ter ondersteuning van hierdie artikel.

\section{UNISA $\cong$}




\section{INLEIDING}

Gewyde liedere en gedigte speel 'n belangrike rol in die Voortrekkervrou Susanna Smit se godsdienstige dagboeke. ${ }^{2}$ Hieronymus van Alphen (1746-1803) is een van die Nederlandse lieddigters na wie sy meermale verwys. ${ }^{3}$ Op gevoelvolle wyse verklaar sy haar dankbaarheid dat Jesus Christus haar aan die wêreldse onttrek het en "met zijne liefling van Alphen heeft leren zingen". ${ }^{4}$ Sy verwys ook na die gesange van Schutte - 'n digter wat nie in die bestaande biografieë oor Susanna Smit geïdentifiseer kon word nie. In sy andersins voortreflike studie oor die lewe van Susanna skryf Karel Schoeman dat die betrokke bron moontlik Willem Sluiter (1627-1673) se Psalmen, Lofzangen ende Geestelijke Liedekens is. ${ }^{5}$ Soos voortaan sal blyk, hou dit geen verband met Sluiter nie, maar wel met die piëtistiese gesangdigter Rutger Schutte (1708-1784). Die identifikasie van hierdie bron as synde die populêre gesangbundel van dié Nederlandse digter en gesangskrywer maak dit moontlik om belangrike aspekte van Susanna Smit se godsdienstige mentaliteitsprofiel in konteks te plaas, dit beter te verstaan en die verband daarvan met ander aspekte van haar godsdienstige lewe te rekonstrueer. Soos by Schutte, staan die pelgrimsmotief sentraal tot Susanna Smit se spiritualiteit. Voorts staan dit eweseer in verband met die spanningsveld tussen die aardse Jerigo en die hemelse Jerusalem, die strewe na praktiese vroomheidspiritualiteit en die gebruik van bruilofsmetafore om die verhouding van Christus tot die gelowige siel te versinnebeeld.

\section{RUTGER SCHUTTE EN DIE VOORTSTUWENDE PIËTISME IN NEDERLAND}

\section{Die ontluiking van 'n nuwe sangkultuur}

Rutger Schutte is gebore te Diepenheim op 29 November $1708 .{ }^{6}$ Volgens P.G. Witsen Geysbeeck was Schutte 'n afstammeling "uit een eerlijk en braaf geslacht, hetwelk onder deszelfs voorvaderen een' martelaar telde". ${ }^{7}$ Op jeugdige leeftyd ontvang

2 Kyk bv. Susanna Smit, Dagboeke. Ongepubliseerde Godsdienstige Oordenkings, 1842-1863, Natalse Argiefbewaarplek, Pietermaritzburg, 1842-1863, band 28, p. 3 (vervolgens word slegs verwys na die band en die betrokke bladsy(e) bv. 28, p. 3). Kyk ook 28, pp. 4-12; 28, pp. 28-29; 28 , pp. $33-34 ; 30$, p. $1 ; 31$, p. $26 ; 32$, p. $1 ; 33$, p. $1 ; 33$, p. 11.

$3 \quad$ Kyk bv. Dagboeke 2, p. 13; 2, p. 41; 6, p. 52; 8, pp. 40, 41; 18, p. 30; 23, p. 14 en 28, p. 15.

4 K. Schoeman, Die Lewe van Susanna Smit, 1799-1863. Kaapstad: Human \& Rousseau, 1995, p. 175.

5 Kyk Schoeman, 1995, p. 175.

6 A.J. van der Aa, Biographisch Woordenboek der Nederlanden. Deel 20. Haarlem: J.J. van Brederode, 1877, p. 558.

7 P.G. Witsen Geysbeeck, Biographisch Anthologisch en Critisch Woordenboek der Nederduitsche Dichters, Deel 5. Amsterdam: C.L. Schleijer, 1824, p. 249. 
hy onderrig in Latyn van sy grootvader, Rutger Couper, predikant te Rekken in Gelderland. ${ }^{8}$ Ná laasgenoemde se oorlye in 1723 besoek Schutte die Latynse skool te Deventer (1723-1729) en woon die lesings van onder andere Hieronymus Simonsz van Alphen (1665-1742) en Johan van den Honert (1645-1730) te Utrecht by. In 1735 word hy deur die Klassis van Amsterdam as proponent aanvaar en op 13 Januarie 1737 te Rossen bevestig. ${ }^{9}$ Daarna vertrek hy na Zalt-Bommel, Dordrecht en Amsterdam. Vanweë liggaamsongesteldheid en daaropvolgende verlamming, lewer hy sy laaste preek op 16 Mei $1776 .{ }^{10}$ Van Schutte se werksaamhede in die aandskemering van sy lewe, skryf Ludovicus Hamerster (1727-1789): “"t (b)ehaagde den Heere hem, kort na dit laatste nog met veel opgewektheid, door hem volbragte werk, met een zwaar kolijk te bezoeken, 't gene men dagt dat een einde van zijn leven gemaakt zou hebben, en tot gevolg had, eene zware verlamming aan zijne zoo werkzame handen." ${ }^{11} \mathrm{Hy}$ sterf op 19 Desember 1784 - "een zacht en zalig einde aan het zoo welbesteed leven des braven mans". ${ }^{12}$ Op 2 Januarie 1785 is sy nagedagtenis deur sy ampsgenoot en swaer Hamerster met 'n Lijkrede, en 'n versameling Lijkzangen vereer. ${ }^{13}$ Schutte se bydraes op uiteenlopende terreine noop Witsen Geysbeeck om hom te beskryf as "een geleerd en in verscheiden wetenschappen ongemeen ervaren man; vooral in de tijdrekenkunde der gewijde schriften, over welke hij een helder licht verspreidde, daarbij een verdienstelijk godsdienstige digter". ${ }^{14}$ Hoewel Geysbeeck met agting na Schutte se Stichtelijke Gezangen verwys, vind hy die akademiese inslag van en klem op Joodse oudheidkunde negatiewe aspekte van Schutte se digwerk: "eene verkeerde hoogdrawendheid en smakelooze opgeblazenheid." Sommige gesange, verklaar Witsen Geysbeeck: "zijn opgesteld om de geleerden noten, die eigenlijk meestal voor Joden belangrijker zijn dan voor Christenen, aan de man te helpen." As voorbeeld noem hy Schutte se "Reize uit Egypte naar Kanaän", wat as 'n "Joodsch gezang", " "schot van geleerdheid in de noten bevat" en wat "als het ware den tekst verdringen". ${ }^{15}$ Die effek van Schutte se Joodse hoogdrawendheid, volgens Witsen Geysbeeck, had tot gevolg dat eersgenoemde groter vordering in die digkuns kon behaal het, "als hij zich door dien wansmaak niet te zeer had laten beheerschen". ${ }^{16}$

R.B. Janssonius skryf Schutte se voorliefde vir geleerde Ou Testamentiese annotasies toe aan sy besondere aangetrokkenheid tot die Joodse oudheid -'n neiging

$8 \quad$ Van der Aa, 1877, p. 558.

$9 \quad$ Van der Aa, 1877, p. 558.

10 Witsen Geysbeeck, 1824, p. 249.

11 L. Hamerster, Leerrede Over het Godvruchtig Leven en Zalig Afsterven van...Rutger Schutte, in Leven Zeer Geacht Kerkleeraar te Amsteldam... Amsterdam: Joh. Wessing, 1785, p. 20.

12 Witsen Geysbeeck, 1824, p. 250.

13 Witsen Geysbeeck, 1824, p. 250.

14 Witsen Geysbeeck, 1824, p. 252.

15 Witsen Geysbeeck, 1824, p. 253.

16 Witsen Geysbeeck, 1824, p. 254. 
wat sy gesange met 'n skyn van oordrewe geleerdheid beklee. ${ }^{17}$ Die populariteit van Schutte se gesange word deur Janssonius toegeskryf eerder aan die invloed van Schutte se eerbiedwaardige aansien as aan die liedere as sodanig, "die in weerwil van de geleerde verklaringen, aan de harten der zangers vreemd bleven". Janssonius voeg by dat Schutte se stigtelike poësie nie so lig vergete sou wees "(h)ad hy meer Davids psalmtoon dan dien van Salomons hooglied zoeken te volgen en meer in den geest dan in de letter der Oostersche poezy zijne kracht gezocht". ${ }^{18}$

Die inspirerende effek van en liefde vir Schutte se sangdigwerk het dieper en wyer gestrek as wat die kritici van sy akademiese aanslag gemeen het. In sy Lijkzang op den Weleerwaarden Heer Rutger Schutte, het H.G. Oosterdyk die leemte wat Schutte se werk tot gevolg had, betreur. Volgens Oosterdyk is Schutte se dood ervaar as "(d)er gantsche Christenskaar in "t zuchtend Nederland". ${ }^{19}$ In die Lijkzangen op den Weleerwaardigen Heer Rutger Schutte (1785) van Z.H. Alewijn, G. de Haas, H.G. Oosterdijk en andere word die volksliefde vir Schutte se digsange in verhewe uitdrukkings besing: "O heil'ge poëzy, gy waart zijn lievelinge./ Hoe zweefd' hy op den klank/ van citer en van harp. Dat elk nu lied' ren zinge,/ En zingend Schutte dank." 20 Janssonius skryf dat in die gemeentes waar Schutte werksaam was, "velen naar zijne taal luisterden en gretig naar de bundels grepen". ${ }^{21}$ Veral jonger gelowiges is deur Schutte se gesange aangevuur, "(h)ier en ginds vereenigden zich in de steden jeugdige vrienden en vriendinnen van toon- en dichtkunst, om met elkander zich in het zingen der geroemde melodiën te oefenen". ${ }^{22}$ Bygevolg het' $n$ ongekende geesdrif vir die gesange ontluik: "Een tijd lang scheen er in sommige kringen een geestdrift te zijn ontwaakt, die de voortreffelijksten uit de jongeren medesleepte en waarvan het levende geslacht geen voorbeeld kon aanwijzen." ${ }^{23}$ Ook Johannes Eusebius Voet (1706-1778) vermeld die ongekende populariteit van Schutte se digsange sodat: "men te 's Hage, by fluit en bas de liederen van Schutte gaarne zong en dat de Delftsche voorstad het orgel sloeg op zijne wijzen, zoodat hy daar in ' $t$ Godshuis, reeds eene geheele schare openlijk met lied op lied, op verheven toon den Heiland had hooren prijzen." 24 Selfs streng gereformeerde kerkgangers soos Egbert de Goede (oorlede 1852) van Doesburg, wat openlik in verset was teen die psalmberyming

17 R.B. Janssonius, Geschiedenis van het Kerkgezang by de Hervormden in Nederland. Tweede druk. Amsterdam: K.H. Schadd, 1863, pp. 130-131.

18 Janssonius, 1863, p. 131.

19 H.G. Oosterdyk, Lijkzang op den Weleerwaarden Heer Rutger Schutte... Geen plek van uitgawe en uitgewer vermeld; ongedateerd (c. 1785); ongepagineerd.

20 Lyksang van Zacharias Henric Alewijn (1742-1788) in Z.H. Alewijn, G. de Haas, H.G. Oosterdijk e.a., Lijkzangen op den Weleerwaardigen Heer Rutger Schutte... Amsterdam: Johannes Wissing, 1785, p. 3.

21 Janssonius, 1863, pp. 128-129.

22 Janssonius, 1863, p. 129.

23 Janssonius, 1863, p. 129.

24 Janssonius, 1863, p. 129. 
van 1773, omdat dit afwyk van die "oude beproefde gereformeerde leer", het as jongman met 'n musiekgeselskap in Zwartsluis, hom verlustig in die liederebundels van Rutger Schutte terwyl die melodieë van die nuwe gesange sy kunssinnige gevoel sterk aangespreek het. ${ }^{25}$

Eusebius Voet, wat homself ook van bestaande melodieë vir sy gesange laat bedien het, wend hom eweneens tot die mees begaafde toonkunstenaars om nuwe sang- en speelwyses vir sy digliedere te vind. ${ }^{26}$ Dié invloed was nie tot Voet se stigtelike digwerk beperk nie: ook sy vriende Bernardus Elikink (1701-1767) en Hendrik Matthysz Lussing (oorlede 1784) het by Schutte se voorbeeld gebaat, terwyl jonger digters soos Hieronymus van Alphen en Pieter Leonard van de Kasteele (1748-1810) se pennevrugte grootliks die resultaat was van "de Amsterdamsche kerkleraar...als de man van wien de opwekking eigenlijk is uitgegaan". ${ }^{27}$ Bygevolg ken Janssonius aan Schutte "eene plaats der eere" toe vir sy bydrae tot die stigtelike sangkuns in Nederland. ${ }^{28}$

\section{DIE KULTIVERING VAN 'n PIËTISTIESE GODSDIENSKULTUUR}

\section{Die piëtistiese vroomheidstrewe}

S.D. Post identifiseer ses kern-temas van die gereformeerde Piëtisme: wedergeboorte; die stryd teen verwêreldliking; geestelike verlating; blydskap as vrug van die geloof; 'n hemelsbegeerte; nagmaalsliriek; en die spreke in Ou Testamentiese taal. ${ }^{29} \mathrm{By}$ Schutte is dit veral die praktiese vroomheidsug wat opval; die wêreldse stryd van die gelowige sondaar in die spanningsveld tussen die hemelse en die aardse en die metaforiese toespelings op Ou Testamentiese bruilofsmetafore. Dié temas kom in wisselende mate, maar deurgaans prominent, in Schutte se digsange voor. Dié temas in Schutte se byderwetse aanslag tot stigtelike sang, het aansluiting gevind by die voortstuwende piëtistiese gees wat oor Europa vaardig was. Veral die praktiese vroomheidsklem het dikwels in Schutte se gesange tot uiting gekom. Oor Schutte

25 E. de Goede, Eene Korte en Eenvoudige Beschrijving van den Weg Der Bekeering dien de DrieEenige Verbonds-God met mij Gehouden Heeft. Doesburg: J.C. van Schenke Brill, 1870, p. 12; F. Van Lieburg, Levens van Vromen. Gereformeerd Piëtisme in de Achttiende Eeuw. Kampen: Uitgeverij De Groot Goudriaan, 1991, p. 137. Vir Schutte se bydrae tot popularisering van stigtelike musiek, kyk F. Schouten, "De Liedboeken van Rutger Schutte. Aantekeningen bij een poging tot Geestelijke Huismuziek uit de Tweede Helft der Achttiende Eeuw," in Mens en Melodie, 24 (1969), pp. 169-172.

26 Janssonius, 1863, p. 129.

27 Janssonius, 1863, p. 131.

28 Janssonius, 1863, p. 131.

29 S.D. Post, Pieter Boddaert en Rutger Schutte: Piëtischtische Dichters in de Achttiende Eeuw. Houten: Den Hertog, 1995, p. 355 e.v. 
se opregte vroomheid was min twyfel. Ludovicus Hamerster se Leerrede over het Godvrugtig Leven en Zalig Afsterven van...Rutger Schutte, in Leven Zeer Geacht Kerkleeraar te Amsteldam (1785) maak melding van Schutte se Christosentriese fokus: "Scopus vitae Christus, dat is: Christus het doel van 't leven. Dit was niet alleen de zinspreuk, die uwe in God rustende Leraar voor zig verkooren had, maar daar in had hij ook zijn welgevallen, daar stelde hij zijn eer en zaligheid in." ${ }^{30}$ Van Schutte se liefde vir Christus en die effek wat dit op persone in sy invloedskring had, voeg Hamerster by:

Gij, dierbare Gemeente! hebt hem gekend, als een man die zijne ziel voor den naam van Jesus had overgegeven. - Hij was een kragtig en uitmuntend bidder, een getrouw verkondiger van Immanuëls liefde tot zondaars - en begaafd met een diep doorzigt in de verdorvenheid van het hart, in de listen van den satan en van het ongeloov, in het ontdekken van de nietige droggrondend. - Bij opgewekt zielen was hij een Barnabas; hij wist op het liefderijkst hare zwarigheden te onderscheppen, met den moeden een woord ter regter tijd te spreken; en het zwakke aan te hangen. ${ }^{31}$

Van sy digterlike styl verklaar A.J. van der Aa dat hy nie soseer op profetiese aspekte klem lê nie, maar tot die geledere van digters behoort wat in "taal- en geskiedkunde, zeggenskracht en het vermogen, om de waarheden zielroerend op het gemoed aan te dringen", uitmunt. Behalwe vir twee lykredes op Willem IV, was van sy bekendste teologiese werke die Leerredenen over de Psalmen (1761); twee Verhandelingen, behelzende eene Verklaaring van Gods Testament en Verbond onder de Nieuwe Huishouding en derzelver zegelen en een onderzoek nopens den aard van 't Verlossing en 't Genade Verbond (1783). Hy verwerf veral bekendheid om sy Verhandelinge over een gedeelte van Salomon's Hooglied; Godspraken van Jeremia; Ontleding der Psalmen; Geslachtboom van Adam tot Christus... (1782) en Verhandeling over de Zeventig Weken van Jeruzalems herbouwing, en Eene Week van Deszelfs Verwoesting (1776-1779). As taalkundige het Schutte, benewens Nederlands, oor taalvaardigheid in Italiaans, Frans en Duits beskik. Dít was een van die redes vir sy benoeming as afgevaardigde van die State van Holland en Wes-Friesland op die kommissie ter samestelling van die nuwe Psalmberyming. Soos sy vriend, Eusebius Voet, verwerf Rutger Schutte veral bekendheid as stigtelike digter. Sy Stichtelijke Gezangen verskyn tot 1787 en beleef drie herdrukke. In 1788 gee Ahasveros van den Berg (1733-1807) nog 'n bundel Nagelatene Gedichten van Schutte uit. Waensel, wat 'n lyksang op Schutte gedig het, beskyf hom as "een zanger vol vuur", 'n "Dawid van zijn tijd", terwyl Jacobus Tol hom voorstel as "een puik poeët en hemelharpenaar, de eer der beste poezy". ${ }^{2}$

30 Hamerster, 1785, p. 19.

31 Hamerster, 1785, p. 19.

32 A.J. van der Aa, 1877, p. 558. 
Hoewel Schutte se aanslag in sommige kringe as oormatig akademies ervaar is, het die opregte vroomheid wat uit sy digsange straal, wyd en syd ontvanklike gemoedere gevind. Deelhebbers aan die agttiende eeuse godsdienstige "gezelschappen" het spontaan by Schutte se spiritualiteit aanklank gevind. Huisoefeninge van vromes waar gelowiges kon bid en sing, terwyl iemand uit die kring, "al naar gelang de Geest hem dreef, "een woord' sprak!" 33 , het hoofsaaklik van die populêre liederebundels van Voet en Schutte (met sangwyse), wat spesiaal vir dié geselskappe bedoel was, gebruik gemaak.

Klem op die onversoenbares van wêreldse luste en opregte vroomheid is 'n onderskeidende kenmerk van Schutte se Stichtelijke Gezangen. In deel I van dié werk bied sy "Het Dwaallicht" 'n tipiese voorbeeld van sy vroomheidspoësie. In die eerste strofe skets hy die teenpole van verwêreldliking en vroomheid soos volg: "Zou ons een dwaallicht leiden,/ Van waereldlust tot rampen;/ Daar dood'lyke afgronds dampen/ Hunn' stank verspreiden?/ Neen! in al 't aardsche goed/ Vond nooit het vroom gemoed/ Een schynend licht, op 't spoor van woeste heiden." ${ }^{34}$ Schutte benut die metafoor van die wolk- en vuurkolom ter beskrywing van Christus se leiding van die gelowige uit die aardse sonde-duisternis..$^{35} \mathrm{n}$ Voortsetting van die tema van Christus se leiding deur die aardse sonde-bedreiginge, figureer veral prominent in sy "Togt naar de Hemelkust"36: "Wykt nu ondermaansche dingen,/ Wykt nu uit myn oog en oor./ ' $k$ Reis naar den hemel. ' $k$ Wil by ' $t$ afscheid vrolyk zingen./ JESUS zal den storm bedwingen." ${ }^{\prime 37}$ Die verleiding van die wêreld is soos 'n loodgewig wat die gelowige na die aarde druk. ${ }^{38}$ Die troosryke redding van die aardse sondaar wat sy hand na God uitstrek, lei Schutte in sy oordenking op Hosea 2 verse 18 en 19 tot verwerping van die wêreldse knellinge: "Weg zondige ydelheeden;/ Weg valsche Delila;/ Gy bindt niet meer dees leden,/ Nog boeit my tot myn schâ." 39 Van die wêreldse neigings wat Schutte in die gelowige se aardse stryd bespeur, is onder andere "Glorie, wellust, ryke schatten". ${ }^{40}$ In dieselfde sangdig, kondig hy die gelowige se oorwinning oor ydele aardse dinge soos volg aan: "'k Lach om schoonheên, die wat blinken; / 'k Lach om eer, vermaak, en goed; ' 'k Lach om 't ryzen, om het zinken;/ 'k Lach om lof, die daalen moet." ${ }^{\prime 1}$

33 P.J. Buijnsters, Hieronymus van Alphen (1746-1803). Assen: Van Gorcum \& Comp., 1973, p. 54.

34 R. Schutte, Stichtelijke Gezangen, op de Beste Italiaansche, en Eenige in dien smaak Nieuwgemaakte Zangwyzen; bij Verscheidene Gelegenheden Gedicht. Deel I. Amsterdam: Johannes Covens, 1762, p. 17.

35 Schutte, 1762, p. 18.

36 Schutte, 1762, p. 24.

37 Schutte, 1762, p. 24.

38 R. Schutte, Stichtelijke Gezangen, in Verscheidene Gelegenheden Gedicht, en met Aanmerkingen, tot Verstand van Eenige Stukken uit de H. Schrift, Verrijkt. Deel 2. Amsterdam: Johannes Covens, 1764, p. 51.

39 Schutte, 1762, p. 37.

40 Schutte, 1762, p. 50.

41 Schutte, 1762, p. 51. 


\section{Die spanningsveld tussen die hemelse en die aardse}

Volgens Schutte leef die gelowige voortdurend in die spanningsveld tussen die hemelse en die aardse. Die vrome se stryd om dankbaar voor God te lewe word deurlopend deur die duiwel, die wêreld en die verdorwe ego gefnuik. Die metafore wat Schutte gebruik om die wêreldse aanslag te verwoord, sluit in die vrug van verleiding, 'n dwaallig, rotse op die seereis na die hemel en 'n barre woestyn vol kronkelpaaie. ${ }^{42}$ Die bedreiginge wat die gelowige veral in die oog moet hou, is liggaamlike wellus, geld en aardse besittings, eer- en magsug. ${ }^{43}$

Die pelgrimsmotief kom in dié verband by Schutte prominent na vore. ${ }^{44}$ Die wêreld is 'n streek waardeur die gelowige reis onderweg na die hemel. ${ }^{45}$ Reeds in sy gedig in Een Nieuw Bundeltje Uitgeknipte Geestelijk Gezangen... (1755), waartoe onder andere Hieronymus van Alphen bygedra het, open Schutte se digsang "Geestelijke Zeevaart. De reis van Een Ziel naar de Zalige Eeuwigheid" die weg vir geestelike pelgrimsdigte wat in latere werke sou volg. "Geestelijke Zeevaart" bestaan uit nege strofes van twaalf reëls elk. Elke strofe gee blyke van'n belangrike spirituele stap in die Christen se reis na die ewigheid. Die eerste strofe beskryf die bekering en die besef van die verlore siel dat die menslike bestemming nie in die aardse lewe gesetel is nie. Metaforiese toespelings op golwe, 'n onstuimige see en vloed beskryf die wisselende en onstabiele aardse lewe: "Ik dobber op de golven/ Van 's werelds onstuim'ge zee./ Vaak in de vloed bedolven./ Waar krijg ik de ree?"46 Vervolgens wend die siel sigself na die lig van Christus, synde "(m)ijn Schild, mijn Zon, en enig Licht". ${ }^{47}$ Geestelike verlating en worstelende geloof in die aardse duister kom in die derde strofe aan die bod, waarna die geloof as enigste anker van die twyfelende siel in die vierde strofe beskryf word. ${ }^{48}$ Die vyfde strofe verwoord die ervarings van die beproefde siel, deur aardse storms geteister, wat Jesus as enigste toevlug het: "'k Zal bij Jezus blijven,/ Dien 'k mijn nood vertel." ${ }^{49}$ Die besef dat die siel nie uit eie krag die hemelse bestemming kan bereik nie, dat slegs die "Wind van 's Hemels Geest!" die sieleskip kan voortdryf en die hemelse bruilofsfees nie op eie stoom bereik kan word nie, is die belangrikste elemente in die sesde strofe. ${ }^{50}$ Vervolgens word beskryf hoe die geloof die geestelike seevaart rig en koersvas begelei. ${ }^{51}$ Geloofsversekering

42 Post, 1995, p. 365.

43 Post, 1995, p. 366.

44 Post, 1995, p. 366.

45 Kyk Schutte, 1762, p. 8; III.

46 Een Nieuw Bundeltje Uitgeknipte en Geestelijke Gezangen ten Dienste Aller Bond- en Gunstgenoten van Jehovah, den Drie-Eenigen en Algenoegzamen God. Elfde druk. Dordrecht: Johan Georg Wittich, 1755, p. 49.

47 Een Nieuw Bundeltje, 1755, p. 49.

48 Een Nieuw Bundeltje, 1755, p. 50.

49 Een Nieuw Bundeltje, 1755, p. 50.

50 Een Nieuw Bundeltje, 1755, p. 50.

51 Een Nieuw Bundeltje, 1755, p. 51. 
in die aanblik van die dood, bevestig aan die geestelike seevaarder die ondersteuning van Gods Gees: "O Geest, vat Gij mijn hand!/ Dierbaar Onderpand!/ Hier is 't eind van "t strijden./ Hier is mijn Vaderland." 52 Die laaste strofe beskryf metafories die aankoms van die gelowige siel in veilige hawe wanneer die geloof oorgaan in aanskoue. ${ }^{53}$

In sy Stichtelijke Gezangen verwissel die pelgrimsmetafore: die Ou Testamentiese Eksodus-metafore van die vuur-en wolkkolom neem die plek van die spirituele seereis in Schutte se vroeëre werk. Eersgenoemde metafore is by Schutte sinnebeeldige afskaduwinge van Christus se verlossingswerk in die wêreld. Die digsang "Reize naar Jerusalem" vorm in bepaalde opsigte die fokus van die pelgrimsmotief in die bundel. Teenoor die slawerny van aardse sonde, stel Schutte die hemelse Kanaän. ${ }^{54}$ Die lig wat die weg daarheen aandui, word metafories beskryf as 'n vuurkolom. ${ }^{55}$ Christus is meteen die vuurkolom wat die gelowige siel na die salige bestemming moet lei: "Immanuël,/ Myn lust en leven,/ Die rust kunt geeven,/ O levenswel.""56 Die laaste twee strofes beskryf die bystand wat Christus die gelowige siel op die spreekwoordelike weg vanuit die aardse Jerigo na die hemelse Jerusalem bied. ${ }^{57}$

Elders in die bundel word Jesus as wolk- en vuurkolom op die reis na die ewige Jerusalem voorgestel. In sy "'t Offer van Zig Zelven" bid hy om Christus se bystand, "myn wolk- en vuurkolom!" 58 en in die sesde strofe van "Tegenzang na Messias komst," 'n digsang op Psalm 42 verse 7 tot 12, word dit "(v)olg het spoor der Wolkkolom" 59 , terwyl hy in strofe drie van sy "Slotzang om de leiding van de geest der waarheid" ${ }^{00}$ bid om Gods "Hemelwind...(d)ryf de wolk- en vuurkolom". ${ }^{61}$ Hy maak ook melding van die "vuur der Wolkkolom", gevolg deur die gebed dat die lig daarvan die sugtende siel mag begelei. ${ }^{62}$

\section{Bruilofsmetafore}

Schutte se Christosentriese spiritualiteit ontvang 'n verskerpte bruilofsmetaforiese toespitsing. Metaforiese verwysings na die bruilof tussen Jesus en die gelowige siel, toespelings op die band tussen bruid en bruidegom en lofdigte op Jesus as die "beminnelyke Immanuël" is 'n derde opvallende tema in Schutte se Stichtelijke

52 Een Nieuw Bundeltje, 1755, p. 51.

53 Een Nieuw Bundeltje, 1755, p. 51.

54 Schutte, 1762, p. 11.

55 Schutte, 1762, p. 11.

56 Schutte, 1762, p. 11.

57 Schutte, 1762, p. 13.

58 Schutte, 1762, p. 18.

59 Schutte, 1762, p. 33.

60 Schutte, 1762, p. 36.

61 Schutte, 1762, p. 36.

62 Schutte, 1762, p. 146. 
Gezangen. Reeds in die voorrede verduidelik hy dat sy digsange beoog dat "de beminnelyke Immanuël gepreezen, die blank en rood is", en die "gadelooze liefde, welke de Bruidegom der ziel onderging, voor zyne uitverkoorene, doch in zig zelf arme Bruid", besing word. ${ }^{63}$ Hy dank God vir die gewyde sanglus wat in sy siel ontsteek is, "'t een of 't ander gezang ter verheerlyking van mynen grooten Maker, den Bruidegom myner ziele, den Geest der eeuwige liefde, en 't groot werk der genade te zingen, en tans, op verzoek en aandrang van veelen, in 't licht te geeven." 64 Hy begeer dat mense afskeid van die wêreld sal neem en hul geheel en al sal toevertrou en oorgee aan "den Bruidegom der ziel". ${ }^{65}$ Bruilofsmetafore kom oor 'n wye spektrum in die bundel voor: die bruid word opgeroep om Jesus as Koning te besing $^{66}$; Jesus is die bloedbruidegom waarop die gelowige siel sy hoop vestig ${ }^{67}$; Jesus "kiest een naakte Bruid;/ Hy wist haar zonden uit"68 en Gods Gees skenk geloof om die nederige hart aan Gods Seun te verbind. ${ }^{69}$

Hoewel Schutte se benutting van bruilofsmetafore nie prominente mistieke elemente vertoon nie, kom aspekte daarvan in van die latere strofes in drie digsange wel sterker na vore. In sy "De bruidegom in 't eenzaame gevonden. Of zielswerkzaamheid met Christus in een stil lustbosschaadje" beskryf Schutte die ontmoeting van siel en Bruidegom in 'n idilliese omgewing: "Myn Bruigom heeft my hier bescheiden,/ Hier plag Hy 't wollig vee te weiden;/ Hy legert zig in 't blaaken van de zon,/ By deeze koele bron"70; "U duizendmaal myn 'Bruigom noemen;/ 'k Heb duizendmaal met U myn hart vereend,/ Van 't ydele gespeend" 71 en stel die vraag: "Zou iets Uw teed're liefde krenken?" Die antwoord: "O neen! Gy blyft, wat my myn hart verwyt,/ Dezelfde God altyd"72 en "O Liefdevlammen, hemelvuuren,/ O tyd der minnen, zalige uuren,/ My heugt, hoe my myn Goël heeft gekust./ Volmaakte zielenrust!" 73 In soortgelyke trant, maar met minder mistieke toespelings, spreek die siel se verlange na Jesus as bruidegom in "De trouwe van den bruidegom, en herder der ziel" ${ }^{74}$ : Jesus bemin die gelowige siel ${ }^{75}$; op Golgota skenk Jesus as bruidegom die bruidskleed aan die gelowige stryder ${ }^{76}$ en die siel word met

63 Schutte, 1762, Voorrede, p. XXI.

64 Schutte, 1762, Voorrede, p. XXIX.

65 Schutte, 1762, Voorrede, p. XXX.

66 Schutte, 1762, p. 5.

67 Schutte, 1762, p. 16. Kyk ook p. 38.

68 Schutte, 1762, p. 38.

69 Schutte, 1762, p. 38.

70 Schutte, 1764, p. 81.

71 Schutte, 1764, p. 82.

72 Schutte, 1764, p. 82.

73 Schutte, 1764, p. 83.

74 Schutte, 1764, p. 115.

75 Schutte, 1764, p. 117.

76 Schutte, 1764, p. 117. 
die Bruidegom, Jesus, verenig. ${ }^{77}$ In "Immanuëls liefde" besing hy Jesus as sy "Goël, God en broeder", as die siele-bruidegom en Opperheer", as vriend, "Zielenhoeder", die "Vaders Woord", "hoogste Wysheid", wat die skoonheid van die jeug bekoor, die "steunsel van de grysheid". ${ }^{78}$

\section{SUSANNA SMIT EN DIE PELGRIMSMOTIEF IN RUTGER SCHUTTE SE DIGSANGE}

\section{Die Ou Testamentiese pelgrimsmotief, ootmoed en die Christen se reis na die hemel}

Om middernag op 25 September 1843 skiet Psalm 46 vers 6 Susanna Smit te binne, sy kniel, bid tot God en met "een uit zweevende gemoedsgestalte" oordink sy die Here se weë met sy volk - "(b)ezonder met Jakop, Josef, Moses en David"- hoe "vele jaren zij zwervende en verdreven uit vreze voor hunne vijande" en God hulle uiteindelik ontfermend uit hul ellendes verlos had. ${ }^{79}$ Die trek uit die Kaapkolonie - wat sy persoonlik meegemaak het - is vir haar sinnebeeldig van die ontberinge van Gods volk op die ewigheidsreis: alhoewel God moontlik nie die afloop van die Voortrekkers se uittog "tot zulken uit voer van groote zaake bestemd heeft", bespeur sy in dié pelgrimstog 'n parallel met die Israelitiese uittog uit verdrukking, omdat die Voortrekkers ook moes gebuk gaan onder "de zware verdrukkingen en bittere rampen die wij in de Kolonie Kaap de Goede Hoop heeft moet lijden, zijnde of dienen tot de grote Emigracie naar de gewesten van Port Natal", en "(d)e Heere leide het kroos der martelaren uit van onder Ingelsche verdrukking". ${ }^{80}$

Die pelgrimsreis na die ewigheid behoef ' $n$ vrome gemoedsgestalte. Ootmoed, geestelike nederigheid en onderdanigheid aan God is die vroomheidseise waaraan die Christen-pelgrim wat biddend voor God lewe, moet voldoen. 'n Kostelike brokkie filosofies-spirituele bepeinsing is in haar dagboekinskrywing van 14 Junie 1850 te vinde: God verhoor die Christen-bidder wat geestelik-nederig bid, want:

...den ootmoet is zeedig; want de gansche schepping is zeedig; den ootmoet is ernstig, want de ganschen hemel is ernstig, den oncienlyken hemel predikt ernst aan zijn geest en de zienlyken hemel aan zijn oogen; den ootmoet spreekt wynig maar dinkt veel, want God verstaat dien van verre en is een oordeelen der gedachten. Hij roept ook dat gij mij nooit ledig vind, den ootmoet leest Gods woord en overweet dien, en neemt alle beloften geestelijk aan, dezen is hem als eene gordel waarmeede hij de kleederen opzond van vaardiglijk te

77 Schutte, 1764, pp. 119-120.

78 Schutte, 1764, p. 121.

79 Smit, 1842-1863, 4, p. 17.

80 Smit, 1842-1863, 4, p. 17. 
loopen, het is hem tot brood, melk, honig en wijn op de ryze naar den hemel. Den ootmoet zingt psalmen zelfs in...den nacht, want hij heeft lust om God te looven... ${ }^{81}$

Susanna beskou haarself as 'n pelgrim wat op reis na die hemel uit die hand van God leef en deur haar fisieke node verhinder word om blymoedig die weg ten hemele te bewandel. Ten spyte daarvan is sy deurgaans bewus van die Here se onderskraging en die verligting van die juk van haar fisieke en geestelike laste. Die Here skenk verkwikking en voldoende lafenis om onderweg na die ewige bestemming die geloof te behou. ${ }^{82}$ Die pelgrimsreis van die gelowige het 'n Christosentriese fokus en die navolging van Christus - as parallel tot die Ou Testamentiese wolk- en vuurkolom onderweg na die beloofde land - is vir die gelowige die weg na die ewige hemelse bestemming.

\section{"De geopenbaarde godsdienst"}

Vroeg Dinsdagoggend 4 Maart 1846 ontwaak Susanna Smit met bedrukte gemoed en vanweë 'n borsaandoening is sy in 'n neerslagtige bui. Sy ken minstens sommige digsange uit Schutte se Stichtelijke Gezangen uit die hoof en hef die twaalfde strofe van die ses-en-dertigste gesang as wekvers aan - 'n Christosentriese lofsang op die soenverdienste van Jesus: "O JESUS myn Borge,/ Die de eischen vervult; Verligter der zorge;/ Verzoener der schuld:/ Verwerver van 't goede;/ Verlosser der ziel:/ Ontfermer, wiens hoede/ Myn harte beviel." ${ }^{83}$ Nadat sy 'n volgende strofe van dieselfde gesang sing, word sy van die bevindelike teenwoordigheid van Jesus bewus, 'n gewaarwording "wat de redding mijner ziel aan Jezus heeft gekost, het was als of mijns geestes oogen mijn dierbaare Verlosser in Zijn nederige liefde tot Zijn volk zug, als of Hij naar beneden op mij zag, en met luisterende waren het schor gekras van mijn bevende stem ontving". ${ }^{84}$ Voor haar geestesoog sien Susanna hoe sy eendag Jesus met "een helder klaar volmaakt gezond stem looven, niet meer geplaagt door benauwde longen, en vermoeid door pijnen"85; "gewichtig, jonk en vaardig". ${ }^{86}$ In die gees aanskou sy Jesus se "liefderijken aanblikken Zijner vriendelijke oogen, door gene zonden vermoeid, door gene pein zingen afgemat". ${ }^{87}$ Die onderliggende motief in Susanna se oordenking is die beroep op die suiwerende verdienste van Jesus se bloedstorting aan die Kruis. ${ }^{88}$

81 Smit, 1842-1863, 42, p. 28.

82 Smit, 1842-1863, 28, p. 32.

83 Schutte, 1762, p. 102.

84 Smit, 1842-1863, 20, p. 9.

85 Smit, 1842-1863, 20, p. 9.

86 Smit, 1842-1863, 20, p. 9.

87 Smit, 1842-1863, 20, p. 9.

88 Schutte, 1762, pp. 12-13. 


\section{"Reize naar Jerusalem"}

Ongeveer twee maande later - 12 Mei 1846 - word die volgende verwysing na Schutte se Stichtelijke Gezangen in haar dagboek opgeteken. Dié verwysing bevat weereens 'n wekvers uit deel een van Schutte se vierdelige werk. Sy vereenselwig haar met die kinders van Israel wat met manna en vleis in die woestyn verkwik is reisende kinders wat deur God met voedsame spyse versterk is. ${ }^{89}$ Sy beskou dit as metafories van die Christen se reis na die hemel. ${ }^{90}$ Voorts pas sy die worsteling van die gelowige siel in die spanning tussen die hemelse en die aardse ook op haar toe. By die sing van die eerste strofe van die gesang uit die hoof, beklaag sy op soortgelyke wyse haar sondelas: "O...o nacht van zonden/ 'k lag vast gebonden/ God maakt my vrij..." ${ }^{11}$ Dié vereenselwiging met Schutte se gesang dien haar tot "eene aangename verheugenis" "2, "zoo als een Christen op dien rijze zich moeten gevoeld en gedragen, zoo schoon bezongen dat Zijner knecht Schutte tot vervrolijking...bezondere verheugde en bemoedigde mij de 5, 6 en de twee daaropvolgende verzen...". ${ }^{93} \mathrm{Sy}$ bedien haar van die tale Kanaäns om die parallelle tussen haar Christen-reis na die ewigheid en die lotgevalle van Israel in die woestyn onder woorde te bring. Die effek van die slang van siekte wat haar gebyt het, kan slegs ongedaan gemaak word deur op die koperslang te let - 'n toespeling op die vyfde strofe van "Reize naar Jerusalem". ${ }^{94}$

Vier dae later - Saterdagoggend 16 Mei 1846 - wend sy haar weer tot Schutte se gesange - sy sit aan "de voeten van mijn vriend Schutte" en verheug haar "in zijne lieflijke Poëzie". ${ }^{95}$ Sy haal aan uit die sesde strofe van "Reize naar Jerusalem" - 'n teks met verskeie ou Testamentiese beelde uit die Israelitiese pelgrimsreis na die beloofde land: "God slaat de rotsen,/ En dwingt de trotsen,/ Ik zing Hosanna." 96 'n Inskrywing 'n paar dae later bevat 'n aanhaling uit die vierde strofe van dieselfde gesang - dié keer 'n toespeling op die lewensreis wat ten spyte van gevare op die reispad in die geloof onderneem moet word..$^{97}$

Teneerdrukkende omstandighede het dikwels bygedra tot Susanna se stroewe geestesgesteldheid. Die inskrywing van Dinsdag 19 Mei 1846 verwoord haar swaarmoedigheid oor haar seun se vertrek na die "Baaij van Natal". Dié seun, George, se huwelikslewe en sy kwellende beroepsomstandighede was vir sy moeder 'n deurlopende bekommernis. Die vertroostende wete van God se nabyheid en sorg

89 Smit, 1842-1863, 21, p. 2.

90 Smit, 1842-1863, 21, p. 2.

91 Smit, 1842-1863, 21, p. 2.

92 Smit, 1842-1863, 21, p. 2.

93 Smit, 1842-1863, 21, p. 2.

94 Smit, 1842-1863, 21, p. 2.

95 Smit, 1842-1863, 21, p. 25.

96 Schutte, 1762, p. 13.

97 Schutte, 1762, p. 12. 
was egter telkens ' $n$ bron van toevlug vir haar. Die nag voorafgaande aan hierdie inskrywing had sy 'n droom - 'n ervaring waaruit sy ontwaak met die woorde van die vierde strofe van "Reize naar Jerusalem": "Nu reize ik meê;/ "k Vrees geen gevaaren,/ Geen felle baaren/ De roode zee." $" 98$

Vanweë haar beswaarde gemoed had Susanna waarskynlik in Mei 1846 telkens Schutte se gesangverse gelees en oorpeins. Woensdag 20 Mei 1846 ontwaak sy weer met teksgedeeltes van "Reize naar Jerusalem" - dié keer uit die derde strofe: "Immanuël,/ Myn lust en leven,/ Die rust kunt geeven,/ O levenswel...". ${ }^{99}$ Enkele dae later was dit Schutte se metaforiese gebruik van die vuurkolom as lig op die lewensreis wat haar wek: "Myn vuurkolom,/ Ik zou verdwaalen:/ Schiet uwe straalen,/ In 't heiligdom." ${ }^{100}$ Dié teks spreek haar beswaarde gemoed aan omdat sy dag vir dag die nood ervaar om die Here vir lig en krag aan te roep ten einde staande te bly op die smal geloofsweg. ${ }^{101}$ Susanna noem spesifiek haar nooddruftige omstandighede, probleme met bediendes en 'n hovaardige vrou in Pietermaritzburg wat Susanna se onderrig van haar kinders gestaak het met die gevolg dat haar reeds klein inkomste van Rds.126 na Rds. 19 daal. ${ }^{102}$

Die laaste verwysing na Schutte se gesangverse word opgeteken op Woensdagoggend 1 Julie 1846. Nadat sy 'n benouende nag deurgebring het, teken sy haar weklied uit een van haar selfgemaakte verse op: "Eenzaam ben ik en ellendig..." Die troos wat sy vervolgens ervaar, geskied "op zulk eene aller luisterijkste wijze onder geklank van hemelsche trompetten en bazuinen" dat haar gees hemelwaarts vaar "tot mijn liefste Heiland, als een reukoffer". ${ }^{103}$ Die gedagte van die Here Jesus wat nagte in gebed deurbring om geregtigheid vir sy volk te verwerf, bevestig sy versoeningswerk as die "volmaakte en getrauwen Heiland Zijns volks". ${ }^{104}$ Dan sing sy uit die laaste strofe van "Reize naar Jerusalem": "Jerusalem,/ O stad die boven/ Al de Eng'len looven,/ Gy kent myn stem!/ 'k Zal vreê beërven,/ En vreê gevoelen;/ Het zondig woelen,/ Zal eeuwig sterven." ${ }^{105}$ By nabaat wonder sy nadenkend of die engele waarvan Schutte praat, haar hoor: "Waarom zeide Schutte gij kendt mijn stem. Zoude de Englen dat ook hooren, als de kinderen des Heere hunne God loofd?"106

\section{SAMEVATTING}

98 Schutte, 1762, p. 12.

99 Schutte, 1762, p. 11.

100 Schutte, 1762, p. 11.

101 Smit, 1842-1863, 23, p. 30.

102 Smit, 1842-1863, 23, p. 30.

103 Smit, 1842-1863, 23, p. 34.

104 Smit, 1842-1863, 23, p. 34.

105 Schutte, 1762, p. 13.

106 Smit, 1842-1863, 23, p. 34. 
Histories beskou, verteenwoordig die Piëtisme 'n diep en breë godsdienskultuur wat by die aanvang van die agttiende eeu, mede onder die nawerkende invloed van die wysgeer Petrus Ramus (1515-1572), die fokus vanaf die teoreties-Aristoteliese teologie na die geloofspraxis van die alledaagse geloofsbelewing verplaas het. Tereg wys Christina Landman daarop dat benewens die ortodoks-gereformeerde godsdiens aan die Kaap, piëtistiese invloede ook mettertyd op die voorposte werksaam was. ${ }^{107}$ Die prakties-georiënteerde Piëtisme het teenoor die kwynende intellektualistiesverstarde ortodoksie gaandeweg navolging geniet onder alle lae van die Protestantse bevolkings in Engeland (byvoorbeeld Richard Baxter [1615-1691]), Nederland (Hermann Witsius [1636-1708], Conrad Mel [gebore 1665] en andere) en Duitsland (veral Philipp Jacob Spener [1635-1705]) en het dié kern-oortuiging beklemtoon: geloof setel véél dieper as die verstand en val saam met die liefde vir Christus. ${ }^{108}$ Geloof as liefdesbelewenis vir Jesus bring 'n verlowing, 'n huwelik tussen Christus en die siel tot stand. Die intieme en innige aard van dié belewenis kan slegs metafories beskryf word. Geloof is bygevolg die spontane vergestalting van die liefdesband tussen die gelowige siel en Jesus. Dié spontaan-innige spirituele belewenis oorbrug die bipolêre spanning tussen geloof en rede, verstand en gemoed wat ten tyde van die oplewing van die Piëtisme kenmerkend van die ortodokse Protestantse spiritualiteit was. As godsdienskultuur was die Piëtisme nie slegs beperk tot die geleerde katederteoloë van die ortodoksie nie, maar het selfs onder geografies, ekonomies en akademies gemarginaliseerde gelowiges neerslag gevind. Die Kaapse kerkgemeenskap kon ook nie aan die spanning tussen ortodoksie en Piëtisme ontkom nie. Die argwaan van Kaapse predikante jeens die Morawiese sendeling Georg Schmidt en die venynige optrede van die Kaapse kerk teen die piëtisties-geneigde Hervormde leraar Haiko van der Veen, kan as klimakspunte van dié spanninge beskou word. Rutger Schutte se bydrae tot die Protestantse himnologie was 'n belangrike brug om dié spanning tussen ortodoksie en Piëtisme te oorbrug. Die oplewing van 'n nuwe populêre sangkultuur onder Protestante uit alle lae van die bevolking het 'n gemeenskaplike grondslag vir ortodokse gereformeerdes en piëtisties-gesinde gelowiges gebied. In die SuidAfrikaanse pioniersgemeenskappe het Schutte se Piëtisme eweneens op ontvanklike bodem geval. Vir afgesonderde veeboer- en Voortrekkerpioniers het Schutte se populêre gesange die gemoedsgestaltes van geloofspraktisyns, soos Susanna Smit, vertolk, in haar vrome oordenkings geresoneer en haar geloofsbeoefening 'n praktiese lewenservaring gemaak wat die Protestantse geloofswaarhede op 'n nuwe spontane wyse tot uiting gebring het.

107 Christina Landman, "Calvinism and South African Women: A Short Historical Overview", Studia Historiae Ecclesiasticae, October 2009, 35(2), pp. 89-102.

108 Kyk H. Heppe, Geschichte des Pietismus und der Mystik in der Reformirten Kirche, namentlich der Niederlande.. Leiden: E.J. Brill, 1879. 
Ekklesiologies gesproke het die Piëtisme die weg na geloofsbeoefening as lewenspraxis, sowel binne as buite die kerk, beklemtoon. ${ }^{109}$ Die waarheid dat die praktiese beoefening van die geloof nie uitsluitlik 'n kerklike aangeleentheid is nie, het vir trekboer- en Voortrekkerpioniers die sekerheid gebied dat hoewel hulle geografies, ekonomies en akademies as gemarginaliseerde geloof-beoefenaars van die hoofstroom kerklike lewe aan die Kaap afgesny was, alle fasette van hul lewe 'n spirituele fokus op die hemelse en die hiernamaals had. Die spontane stigtelike sang van jongmense wat deur Schutte se digsange aangespreek is, het ver buite die kerklike ruimtes van die gereformeerde ortodoksie neerslag gevind. Susanna Smit was nie alleen gemarginaliseerd wat die Kaapse kerk betref nie. Faksievorming, party-naywer, haar seun George se onstabiele huweliks- en beroepslewe en persoonlike argwaan jeens haar man, Erasmus Smit, het geweldige eise aan haar geloofsbeoefening gestel. Saam met ander piëtistiese werke, kon sy haar egter godsdienstig uit onder andere Schutte se gesange versorg ten spyte van die afstande wat haar geografies van die kerk aan die Kaap en emosioneel van die gemeentelike lewe in Pietermaritzburg geskei het.

Piëtisme beklemtoon dat belyders van die regverdiging uit die geloof in die Protestantse kerke 'n onvoltooide spirituele profiel vertoon, dat geloofsbeoefening 'n wesenlike kenmerk van heiligmaking moet hê en dat die samekoms van vromes in klein, afgeslote kringe 'n belangrike toevoeging ter kultivering van 'n warm affektiewe spiritualiteit is. ${ }^{110}$ Rutger Schutte se gesange staan in dieselfde lyn. Die trekkragte tussen hemel en hel; tussen die hemelse Jerusalem en die aardse Jerigo; tussen Christus en die wêreld deurspek sy digsange. Die grootste kragte waarmee die gelowige pelgrim in dié verband worstel, is die duiwel, die aardse en die eie ek. Dít is ook die kragte waarmee Susanna Smit daagliks in haar godsdienstige en huislike lewe te make had. Schutte se beskrywing van die gelowige se pelgrimsreis deur die ondermaanse na die hemel, die trek vanaf die Kaap na Natal en die vooruitsig van die finale vereniging met Jesus, dien by Susanna ter bevestiging van haar oortuigings dat die gelowige nie finale rus vir sy/haar voet in die lewe op aarde kan vind nie en dat die hemelse Jerusalem die eindbestemming is wat elke dag skerper in spirituele fokus kom.

\section{BRONNELYS}

Alewijn, Z.A., G. de Haas en H.G. Oosterdy. Lijkzangen op den Weleerwaardigen Heer Rutger Schutte... Amsterdam: Johannes Wessing, 1785.

Bavinck, H. Gereformeerde Dogmatiek. Deel 4, tweede druk. Kampen: J.H. Kok, 1911.

109 Vir die piëtistiese neiging tot konventikelvorming kyk A. Ritschl, Geschichte des Pietismus in der Lutherischen Kirche des 17. und 18. Jahrhunderts. Bonn: Adolph Marcus, 1884.

110 Vgl. H. Bavinck, Gereformeerde Dogmatiek. Deel 4. Tweede druk. Kampen: J.H. Kok, 1911, p. 262. 
Buijnsters, P.J. Hieronymus van Alphen (1746-1803). Assen: Van Gorcum \& Comp, 1973.

De Goede, E. Eene Korte en Eenvoudige Beschrijving van den Weg Der Bekeering dien de DrieEenige Verbonds-God met mij Gehouden Heeft. Doesburg: J.C. van Schenke Brill, 1870.

Een Nieuw Bundeltje Uitgeknipte en Geestelijke Gezangen ten Dienste Aller Bond-en Gunstgenoten van Jehovah, den Drie-Eenigen en Algenoegzamen God. Elfde druk. Dordrecht: Johan Georg Wittich, 1755.

Hamerster, L. Leerrede Over het Godvruchtig Leven en Zalig Afsterven van...Rutger Schutte, in Leven Zeer Geacht Kerkleeraar te Amsteldam... Amsterdam: Joh. Wessing, 1785.

Heppe, H. Geschichte des Pietismus und der Mystik in der Reformirten Kirche, namentlich der Niederlande. Leiden: E.J. Brill, 1879.

Janssonius, R.B. Geschiedenis van het Kerkgezang by de Hervormden in Nederland. Tweede druk. Amsterdam: K.H. Schadd, 1863.

Landman, Christina. "Calvinism and South African Women: A Short Historical Overview," Studia Historiae Ecclesiasticae 35, no. 2, (October 2009): 89-102.

Oosterdyk, H.G. c. Lijkzang op den Weleerwaarden Heer Rutger Schutte... Geen plek van uitgawe en uitgewer vermeld; ongepagineerd, 1785.

Post, S.D. Pieter Boddaert en Rutger Schutte: Piëtischtische Dichters in de Achttiende Eeuw. Houten: De Hertog, 1995.

Ritschl, A. Geschichte des Pietismus in der Lutherischen Kirche des 17. und 18. Jahrhunderts. Bonn: Adolph Marcus, 1884.

Schoeman, K. Die Lewe van Susanna Smit, 1799-1863. Kaapstad: Human \& Rousseau, 1995.

Schouten, F. "De Liedboeken van Rutger Schutte. Aantekeningen bij een poging tot Geestelijke Huismuziek uit de Tweede Helft der Achttiende Eeuw." Mens en Melodie, 24 (1969): 169172.

Schutte, R. Stichtelijke Gezangen, op de Beste Italiaansche, en Eenige in dien smaak Nieuwgemaakte Zangwyzen; bij Verscheidene Gelegenheden Gedicht. Deel 1. Amsterdam: Johannes Covens, 1762.

Schutte, R. Stichtelijke Gezangen, in Verscheidene Gelegenheden Gedicht, en met Aanmerkingen, tot Verstand van Eenige Stukken uit de H. Schrift, Verrijkt. Deel 2. Amsterdam: Johannes Covens, 1764.

Smit, S. Dagboeke. Ongepubliseerde Godsdienstige Oordenkings, 1842-1863. Natalse Argiefbewaarplek, Pietermaritzburg, 1842-1863.

Van der Aa, A.J. Biographisch Woordenboek der Nederlanden. Deel 20. Haarlem: J.J. van Brederode, 1877.

Van Lieburg, F. Levens van Vromen. Gereformeerd Piëtisme in de Achttiende Eeuw. Kampen: Uitgeverij De Groot Goudriaan, 1991.

Witsen Geysbeeck, P.G. Biographisch Anthologisch en Critisch Woordenboek der Nederduitsche Dichters. Deel 5. Amsterdam: C.L. Schleijer, 1824. 